\title{
Check dams and storages beyond trapping sediment, carbon sequestration for climate change mitigation, Northwest Ethiopia
}

\author{
Solomon Addisu $^{1 *}$ and Mulatie Mekonnen ${ }^{2}$
}

\begin{abstract}
Background: Global warming as a result of increased greenhouse gases (GHGs) concentration in the atmosphere is threating the existence of life on earth. Reducing the concentration of such gases with sequestering mechanism on the surface of the land helps to treat the problem. One of such methods is trapping carbon in the form of soil organic carbon (SOC) together with sediments, by implementing sediment trapping practices. Direct field measurements, calculations and laboratory analysis were used.

Results: The result shows that sediment storage dams (SSDs) sequestered/trapped $\sim 60.97^{*} 10^{3} \mathrm{t}$ of sediment with the SOC content ranged from 14 to $87 \mathrm{~g} \mathrm{~kg}^{-1}$ and check dams (CDs) trapped $7.8^{*} 10^{3} \mathrm{t}$ of sediment with the SOC content ranged from 20 to $290 \mathrm{~g} \mathrm{~kg}^{-1}$. In general, the studied SSDs and CDs sequestered $\sim 44.68^{*} 10^{5} \mathrm{~kg}$ of SOC together with $\sim 68.8^{*} 10^{6} \mathrm{~kg}$ of sediment. In this study, SSDs and CDs were found to be important SOC sequestering practices together with sediments.

Conclusions: Thus, it is concluded that soil and water conservation structures can be used as carbon sequestering methods to reduce the concentration of GHGs in the atmosphere in addition to reducing soil erosion.
\end{abstract}

Keywords: Soil organic carbon, Soil organic matter, Climate change, Soil and water conservation structures

\section{Introduction}

Global warming will continue being a critical problem in the twenty-first century due to increased carbon dioxide and other greenhouse gases (GHGs) concentration in the atmosphere. The atmospheric concentrations of the greenhouse gases carbon dioxide $\left(\mathrm{CO}_{2}\right)$, methane $\left(\mathrm{CH}_{4}\right)$, and nitrous oxide $\left(\mathrm{N}_{2} \mathrm{O}\right)$ is increasing from time to time. In 2011 the concentrations of these GHGs were 391 ppm, $1803 \mathrm{ppb}$, and $324 \mathrm{ppb}$, which exceeded the pre-industrial levels by about $40 \%, 150 \%$, and $20 \%$, respectively (IPCC, 2013).

The exchange of carbon $(C)$ between soils and the atmosphere is a significant part of the carbon cycle since carbon is a major component of soils as organic matter content. Globally, the soil organic carbon (SOC) pool stores $\sim 1500 \mathrm{PgC}$ in the first one meter depth of soil, which is more carbon than is contained in the atmosphere

\footnotetext{
* Correspondence: soladd2000@yahoo.com

${ }^{1}$ Bahir Dar University, College of Agriculture and Environmental Sciences,

P.o.box 5501 Bahir Dar, Ethiopia

Full list of author information is available at the end of the article
}

$(\sim 800 \mathrm{PgC})$ and terrestrial vegetation $(\sim 500 \mathrm{PgC})$ (FAO and ITPS, 2015) although their distribution is spatially and temporally variable. The $2300 \mathrm{Gt}$ of $\mathrm{C}$ stored in global soil is 3 times the size of the atmospheric $C$ pool and 4.1 times the biotic C pool (Lal, 2003).

SOC is the main component of soil organic matter (SOM). According to FAO and ITPS (2015), SOM contains roughly $55-60 \% \mathrm{C}$ by mass. A high SOM content provides nutrients to plants and improves water availability, which enhances soil fertility and improves crop productivity. Moreover, SOC improves soil structural stability and porosity, which ensures sufficient aeration and water infiltration to support plant growth.

The carbon flux derived from land use change was more predominant in preindustrial times (between 1750 and 2011) in which one-third of all anthropogenic GHGs was derived from land use changes (IPCC, 2014). On a long-term basis, atmospheric $\mathrm{CO}_{2}$ has increased from about 180 to $280 \mathrm{ppm}$ since the last glacial period, adding about $220 \mathrm{PgC}$ to the atmosphere over a 10,000 year 
period at a rate of $\sim 4.4 \mathrm{PgC} \mathrm{yr}^{-1}$ (Baldocchi et al., 2016).

The global soil water erosion process has been described both as a net $\mathrm{C}$ source of around $1 \mathrm{Gt} \mathrm{yr}^{-1}$ (Lal, 2003) and a net $C$ sink of up to $1.5 \mathrm{Gt} \mathrm{yr}^{-1}$ (Stallard, 1998). The carbon-based GHGs emitted by soil are $\mathrm{CO}_{2}$ and methane $\left(\mathrm{CH}_{4}\right)$, which are two of the most leading anthropogenically emitted GHGs (IPCC, 2014). This means dead organic material incorporated into the soil can be potential sources of carbon through organic material transformation by heterotrophic microorganisms. SOC sequestration is the process by which carbon is fixed from the atmosphere via plants or organic residues and stored in the soil. When dealing with $\mathrm{CO}_{2}$, SOC sequestration involves three stages: (i) the removal of $\mathrm{CO}_{2}$ from the atmosphere via plant photosynthesis; (i) the transfer of carbon from $\mathrm{CO}_{2}$ to plant biomass; and (i) the transfer of carbon from plant biomass to the soil where it is stored in the form of SOC (FAO, 2017).

As a result of soil erosion \& deposition processes, the sediments trapped by sediment trapping dams or structures can potentially serve as natural carbon sinks (Poch et al. 2006; Harden et al. 2008; Van Oost et al. 2008; Cao et al. 2009, 2010). The organic carbon content in deposited sediments \& eroded material was over twice that of the original soils (Jacinthe et al., 2004). Globally sedimentation resulting from soil erosion can sequester $\sim 1 \mathrm{Pg} \mathrm{C}$ yr. $^{-1}$ (Stallard 1998; Smith et al. 2001). Dean and Gorham (1998) estimated the organic carbon sequestering role of reservoir sediments with a rate of $0.16 \times 10^{15} \mathrm{~g} \mathrm{yr}^{-1}$. Floodplain sediments have also been documented as potential organic carbon stores up to $0.22 \mathrm{~kg} \mathrm{C} \mathrm{m}^{-2} \mathrm{yr}^{-1}$ (DeLaune and White, 2012; Kayranli et al., 2010).

SOC sequestration for check-dams (CDs) was evaluated in China (Bao, 2008; Wang et al. 2011) based on the sediments volume \& average SOC contents. The result showed that CDs trapped over $21^{*} 10^{9} \mathrm{~m}^{3}$ with an average SOC content of $\sim 3.31 \mathrm{~g} \mathrm{~kg}^{-1}$ (Bao, 2008) and $0.952 \mathrm{Gt}\left(1 \mathrm{Gt}=10^{9} \mathrm{t}=10^{15} \mathrm{~g}\right)$ with an average SOC content of $3.4 \mathrm{~g} \mathrm{~kg}^{-1}$ (Wang et al., 2011).

In Ethiopia, CDs and sediment storage dams (SSDs) have been implemented in large areas as sediment trapping measures, which stored large amounts of sediment (Mekonnen et al., 2015; MERET, 2008). Together with the sediment, these structures are trapping and storing large amount of organic carbon. However, the amount of carbon sequestered together with the sediment and their climate change mitigation role is not yet evaluated (MERET, 2008). According to $\mathrm{Li}$ et al. (2007) and Cao (2008), although CDs, which are widely used to trap sediments in areas with high soil erosion, are acting as carbon sinks, only a few assessments of their carbon sequestration have been performed.

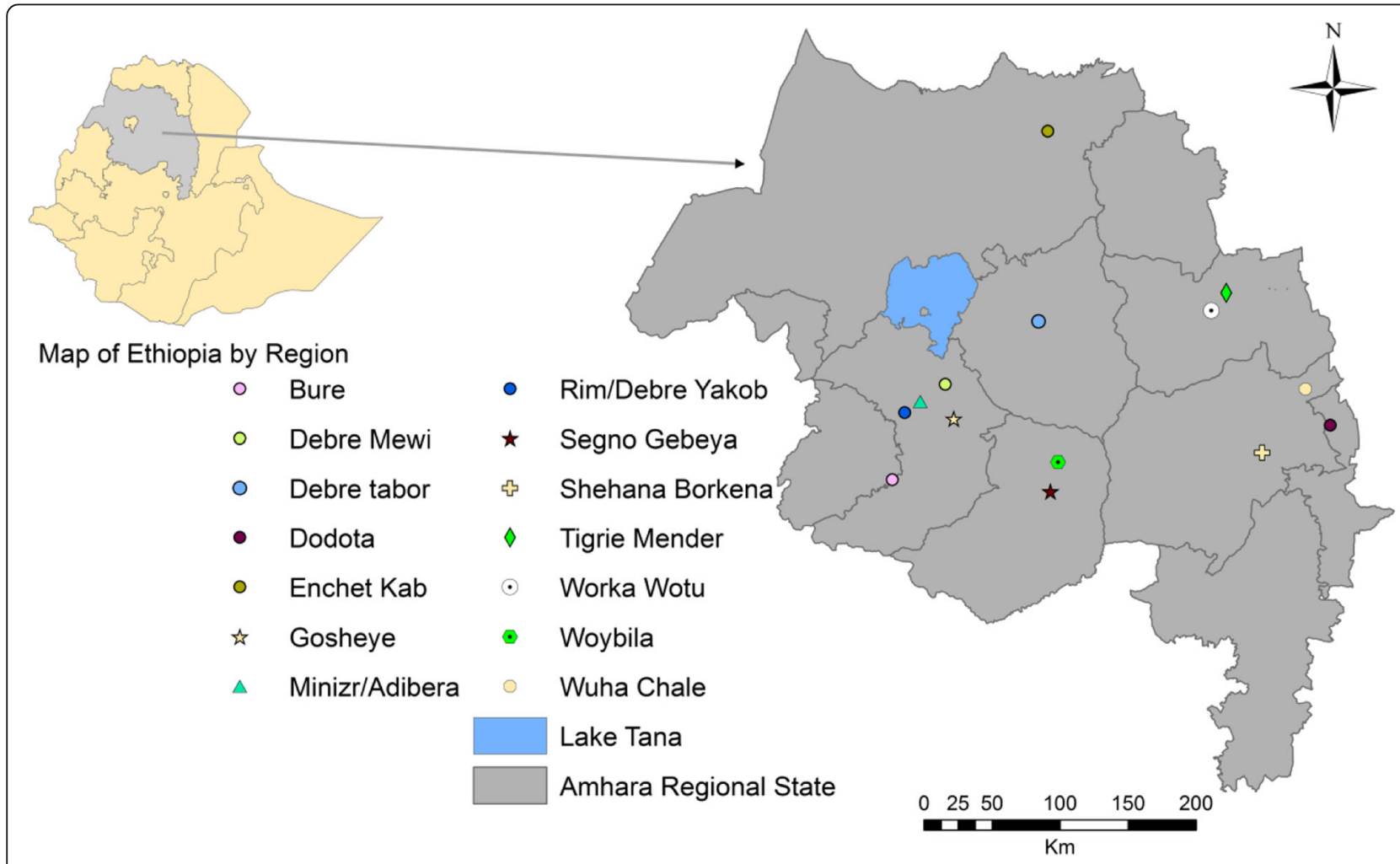

Fig. 1 location map of the study areas 
Therefore, the objectives of this study were to (i) quantify the amount of sediment trapped and stored by check dams (CDs) and sediment storage dams (SSDs) in northwest Ethiopia, (ii) determine the amount of soil organic carbon (SOC) and soil organic matter (SOM) sequestered by CDs and SSDs together with the sediment, and (iii) asses the climate change mitigation role of such sediment trapping structures.

\section{Materials and methods}

\section{Study area description}

The study was conducted in the Amhara National Regional State, northwest Ethiopia (Fig. 1), at eight sediment storage dams constructed at the outlet of micro-watersheds with an area ranging from 35 to 105 ha (Segno Gebeya, Woybila, Shehena Borkena, Enchet Kab, Tigrie Mender, Worka Wotu, Dodota, Wuha Chale) and six check dams constructed within gullies for the purpose of gully treatment (Rim/Debre Yakob, Minizr/ Adibera, Gosheye, Debre Mewi, Debre Tabor and Bure). Farmland is the dominant land use type in each sub-catchment amounting to about $80 \%$ while about $20 \%$ is used as grazing land, eucalyptus plantation and/ or bush land. The slopes in the sub-catchments ranged from $0.4-31 \%$ with dominant average slopes of 11.6$24 \%$.

During site selection difference in soil type, elevation and rainfall amount were considered. Five structures were selected at an elevation less than $2200 \mathrm{~m}$ a.s.l.; five structures between 2200 and $2700 \mathrm{~m}$ a.s.l. and four structures above $2700 \mathrm{~m}$ a.s.l. Difference in soil types were also taken into account such as Nitosols, Cambisols, Leptosols, Regosols and Vertisols. Table 1 summarizes the geographic location (X, Y coordinates), mean annual rainfall, soil type and elevation of each of the study sites.

\section{Research methods Measuring trapped sediment}

In this study, eight sediment storage dams (SSDs) and six check dams (CDs) were selected and the amount of sediment trapped behind each structure was measured based on the geometric nature of the gullies, SSD/CD dimensions and the area of sediment deposition using GPS and measuring tape. Some of the structures have trapezoidal shapes and others have rectangular shapes. Figure 2 shows two example SSDs investigated.

To calculate the volume (V) of the sediment accumulated behind the trapezoidal shape SSDs/CDs, the area $\left(\mathrm{A}, \mathrm{m}^{2}\right)$ of the sedimentation times the length $(\mathrm{L}, \mathrm{m})$, which is from the SSDs/CDs to the end of sedimentation upstream was used (Eq.1). The area (A) of the trapped sediment is the average of the top and bottom widths (b1 and b2; $\mathrm{m}$ ) of the sediment multiplied by its height $(h, m)$ measured from the base of the dam to the sediment surface (Eq.2). For rectangular shape SSDs/CDs, length $(\mathrm{L}, \mathrm{m})$ times width $(\mathrm{W}, \mathrm{m})$ times depth $(\mathrm{D}, \mathrm{m})$ of the trapped sediment was used.

$$
\begin{aligned}
& V=A * L \\
& A=\frac{1}{2}(b 1+b 2) * h
\end{aligned}
$$

\section{Dry sediment mass calculation}

To convert sediment volume, which was directly measured in the field to dry sediment mass, the bulk density

Table 1 Study sites geographical location, soil type, rainfall and elevation

\begin{tabular}{llllll}
\hline $\begin{array}{l}\text { Study sites/ } \\
\text { watersheds }\end{array}$ & X coordinate $(\mathrm{m})$ & Y coordinate $(\mathrm{m})$ & Soil type & Mean annual rainfall (mm) & Elevation (m a.s.l.) \\
\hline Segno Gebeya & 410,030 & $1,204,435$ & Nitosols & 1200 & 2633 \\
Woybila & 410,018 & $1,206,409$ & Nitosols & 1200 & 2685 \\
Shehana Borkena & 584,808 & $1,209,121$ & Cambisol & 850 & 1517 \\
Tigrie Mender & 533,579 & $1,330,784$ & Cambisol & 870 & 2994 \\
Worka Wotu & 532,482 & $1,328,381$ & Cambisol & 870 & 2821 \\
Dodota & 609,971 & $1,233,275$ & Cambisol & 800 & 1627 \\
Enchet Kab & 402,452 & $1,449,577$ & Eutric Leptosol & 1200 & 3135 \\
Wuha Chale & 591,772 & $1,259,992$ & Regosol & 900 & 2100 \\
Rim/Debre Yakob & 305,992 & $1,247,808$ & Nitosols & 1395 & 2130 \\
Minizr/Adibera & 308,594 & $1,250,757$ & Vertisol & 1215 & 2100 \\
Gosheye & 333,102 & $1,238,122$ & Nitosols & 1250 & 2353 \\
Debre Mewi & 327,021 & $1,254,831$ & Vertisol & 1080 & 2230 \\
Debre tabor & 395,600 & $1,309,735$ & Leptosols & 1384 & 2712 \\
Bure & 288,034 & $1,193,482$ & Nitosols & 1365 & 2534 \\
\hline
\end{tabular}




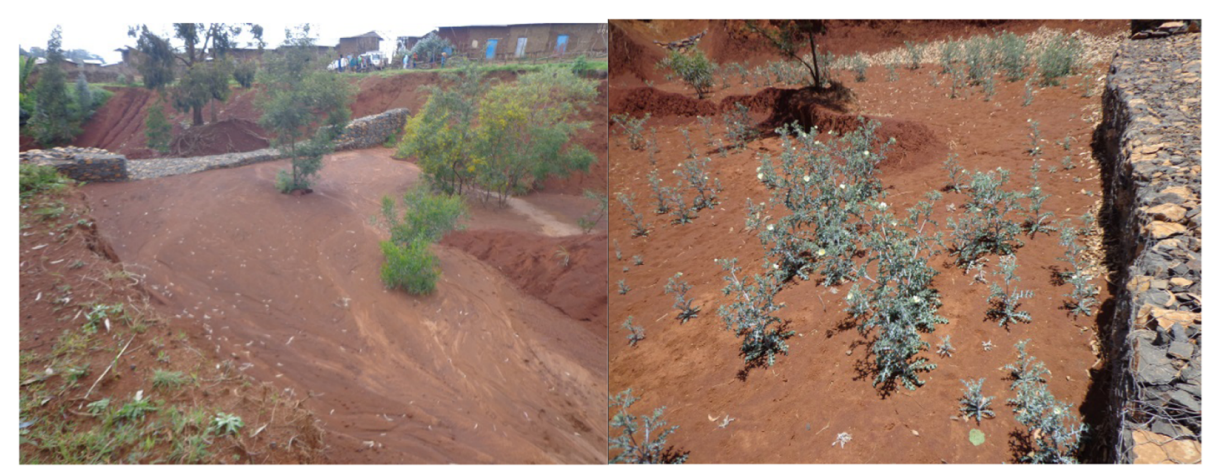

Fig. 2 Example SSD pictures constructed to sequester sediment and SOC two years old (left, Segno Gebeya watershed) and five years old (right, Woybila watershed), in the northwest highlands of Ethiopia

of the trapped sediment was estimated using the cylindrical core method (McKenzie et al., 2002, Mekonnen et al. 2015). In the middle of the deposited sediment from 1 to $1.5 \mathrm{~m}$ deep pit (based on the depth of the deposited sediment) was dugout vertically downward and cylindrical core sampling was done at three locations along the side walls of the dugout pits (upper, middle and lower) inserting the cylindrical core sampler $\left(100 \mathrm{~cm}^{3}\right)$ into the side wall at the desired depth. The collected samples were oven dried at $105^{\circ} \mathrm{C}$ in the laboratory for $24 \mathrm{~h}$ and sediment density was calculated weighing the dried sediment and subtracting it from the wet sediment mass.

\section{Quantifying sediment organic carbon and organic matter}

To quantify the amount of sediment organic carbon (SOC) and sediment organic matter (SOM) sequestered by SSDs and CDs together with the trapped sediment, from 1 to 1.5 $\mathrm{m}$ deep pits were dugout vertically downward in the middle of the deposited sediment behind the SSDs and CDs based on the depth of the trapped sediment. Sampling was done at three locations (upper, middle and lower) along the side of the walls in each pit. Samples collected from the upper, middle and lower locations were thoroughly mixed and 1 kilogram composite sediment sample was taken for laboratory analysis for each location, i.e. $14 \mathrm{~kg}$ composite sediment samples were used for laboratory analysis in total. The Walkley-Black titration method (Nelson and Sommers, 1982), which is one of the cheapest and rapid methods for the analysis of organic carbon (OC) in soils and sediments, was used. Soil organic matter was calculated by multiplying soil organic carbon by a factor of 1.724 .

\section{Results}

\section{Trapped sediment}

The eight SSDs and six CDs investigated, built from gabion and stone trapped a total of $\sim 50.5^{*} 10^{3} \mathrm{~m}^{3}$ or $\sim 68.8^{*} 10^{3} \mathrm{t}$ of sediment $\left(44^{*} 10^{3} \mathrm{~m}^{3}\right.$ or $60.97^{*} 10^{3}$ by SSDs, and $6.5^{*} 10^{3} \mathrm{~m}^{3}$ or $7.8 \mathrm{t}$ by $\mathrm{CDs})$.
Sediment bulk density values ranged from $1.18-1.53 \mathrm{~g}$ $\mathrm{cm}^{-3}$ with an average value of $1.36 \mathrm{~g} \mathrm{~cm}^{-3}$ in the case of SSD sediments and from 1.04-1.32 $\mathrm{g} \mathrm{cm}^{-3}$ with an average value of $1.23 \mathrm{~g} \mathrm{~cm}^{-3}$ in the case of $C D$ sediments. Sediment bulk density is lower in heavy clay sediment deposits and higher in sandy loam dominated sediments. Sediment bulk density of the trapped sediment in SSDs and CDs ranged from $1.04-1.53 \mathrm{~g} \mathrm{~cm}^{-3}$ with an average value of $1.3 \mathrm{~g} \mathrm{~cm}^{-3}$. Table 2 shows volume, mass and bulk density of the trapped sediment behind each SSDs and CDs.

\section{Sediment organic carbon and organic matter}

Through laboratory analysis, the deposited mass of SOC and SOM were determined (Table 3). SOC trapped by SSDs ranged from 14 to $87 \mathrm{~g} \mathrm{~kg}^{-1}$ of sediment. SOM trapped by SSDs ranged from 24 to $147 \mathrm{~g} \mathrm{~kg}^{-1}$ of sediment. SOC trapped by CDs ranged from 20 to $290 \mathrm{~g} \mathrm{~kg}^{-}$ ${ }^{1}$ of sediment. SOM trapped by CDs ranged from 35 to $530 \mathrm{~g} \mathrm{~kg}^{-1}$ of sediment.

The evaluated eight SSDs trapped $\sim 28^{*} 10^{5} \mathrm{~kg}$ SOC and $56.6 * 10^{5} \mathrm{~kg}$ SOM together with $61^{*} 10^{6} \mathrm{~kg}$ sediment and the six CDs trapped $16.68 * 10^{5} \mathrm{~kg} \mathrm{SOC}$ and $29.2 * 10^{5}$ $\mathrm{kg}$ SOM together with $78^{*} 10^{6} \mathrm{~kg}$ sediment. A kilogram of sediment contains $47-59 \%$ more SOM compared with SOC (Table 3 and Fig. 3). SOC and SOM contained in a kilogram of sediment showed direct correlation with $\mathrm{R}^{2}$ $=0.99$ (Fig. 4). In general, the studied SSDs and CDs sequestered $\sim 44.68^{*} 10^{5} \mathrm{~kg}$ of SOC and $85.8^{*} 10^{5} \mathrm{~kg}$ SOM together with $\sim 68.8^{*} 10^{6} \mathrm{~kg}$ of sediment.

\section{Discussion}

Role of SSDs and CDs practices in trapping sediment

Rising soil erosion emphasises the need to trap sediment along the sediment transfer pathways. Dam construction of both large and small sizes to trap sediment can reduce soil erosion, downstream sedimentation, flooding and other environmental problems. Sediment storage dams (SSDs) and check dams 
Table 2 Volume and mass of sediment trapped by SSDs and CDs

\begin{tabular}{llll}
\hline SSDs & Trapped sediment $\left(\mathrm{m}^{3}\right)$ & Bulk density $\left(\mathrm{g} / \mathrm{cm}^{3}\right)$ & Total trapped sediment $(\mathrm{t})$ \\
\hline Segno Gebeya & 3240 & 1.33 & $4.31^{*} 10^{3}$ \\
Woybila & 15,920 & 1.36 & $21.65^{*} 10^{3}$ \\
Shehena Borkena & 6156 & 1.53 & $9.42^{*} 10^{3}$ \\
Tigrie Mender & 1321 & 1.42 & $1.88^{*} 10^{3}$ \\
Worka Wotu & 1516 & 1.18 & $1.79^{*} 10^{3}$ \\
Dodota & 1085 & 1.31 & $1.4^{*} 10^{3}$ \\
Enchet Kab & 7593 & 1.40 & $10.63^{*} 10^{3}$ \\
Wuha Chale & 7167 & 1.38 & $9.89^{*} 10^{3}$ \\
Sum & $\sim 44^{*} 10^{3}$ & & $60.97^{*} 10^{3}$ \\
CDs & Trapped sediment $(\mathrm{m} 3)$ & Bulk density $\left(\mathrm{g} / \mathrm{cm}^{3}\right)$ & Total trapped sediment $(\mathrm{t})$ \\
Rim/Debre Yakob & 1425 & 1.04 & $1.48^{*} 10^{3}$ \\
Minizr/Adibera & 980 & 1.15 & $1.13^{*} 10^{3}$ \\
Goshye & 854 & 1.21 & $1.03^{*} 10^{3}$ \\
Debre Mewi & 1232 & 1.29 & $1.59^{*} 10^{3}$ \\
Debre Tabor & 897 & 1.32 & $1.18^{*} 10^{3}$ \\
Bure & 1087 & 1.29 & $1.40^{*} 10^{3}$ \\
Sum & $\sim 6.5^{*} 10^{3}$ & & $\sim 7.81^{*} 10^{3}$ \\
Total & $\sim 50.5^{*} 10^{3}$ & & $\sim 68.8^{*} 10^{3}$ \\
\hline
\end{tabular}

(CDs) are soil and water conservation practices constructed in large areas of Ethiopia by Governmental offices and non-governmental organization with the objective to trap sediment and reduce soil erosion (Mekonnen et al. 2014; Mekonnen et al. 2015; MERET, 2008). SSDs are physical structures or barriers made of stone or gabion mostly constructed at the outlets of catchments and CDs are physical structures like SSDs but mostly constructed within gullies.

The sediment trapping role of eight SSDs and six CDs were investigated in this study and the result shows that SSDS trapped $44^{*} 10^{3} \mathrm{~m}^{3}$ or $60.97^{*} 10^{3} \mathrm{t}$ and CDS trapped $6.5^{*} 10^{3} \mathrm{~m}^{3}$ or $7.8^{*} 10^{3} \mathrm{t}$ of sediment. Both SSDs and CDs trapped a total of $\sim 50.5^{*} 10^{3} \mathrm{~m}^{3}$ or $\sim 68.8^{*} 10^{3} \mathrm{t}$ of

Table 3 SOC and OM trapped by SSDs and CDs

\begin{tabular}{|c|c|c|c|c|c|}
\hline SSDs & SOC kg kg ${ }^{-1}$ sediment & SOM kg kg-1 Sediment & Trapped sediment (kg) & Total SOC Trapped (kg) & Total SOM Trapped (kg) \\
\hline Segno Gebeya & 0.028 & 0.048 & $43.09 * 10^{5}$ & $120.66^{*} 10^{3}$ & $206.84^{*} 10^{3}$ \\
\hline Woybila & 0.014 & 0.024 & $216.51 * 10^{5}$ & $303.12^{*} 10^{3}$ & $519.63^{*} 10^{3}$ \\
\hline Shehena Borkena & 0.06 & 0.102 & $94.19 * 10^{5}$ & $565.12^{*} 10^{3}$ & $979.54^{*} 10^{3}$ \\
\hline Tigrie Mender & 0.03 & 0.051 & $18.76^{*} 10^{5}$ & $56.27^{*} 10^{3}$ & $962.29 * 10^{3}$ \\
\hline Worka Wotu & 0.032 & 0.055 & $17.89 * 10^{5}$ & $57.24 * 10^{3}$ & $98.39 * 10^{3}$ \\
\hline Dodota & 0.022 & 0.037 & $14.31 * 10^{5}$ & $31.49 * 10^{3}$ & $52.96 * 10^{3}$ \\
\hline Enchet Kab & 0.087 & 0.147 & $106.30 * 10^{5}$ & $924.83^{*} 10^{3}$ & $1583.9^{*} 10^{3}$ \\
\hline Wuha Chale & 0.075 & 0.128 & $98.91 * 10^{5}$ & $741.79 * 10^{3}$ & $1256.09 * 10^{3}$ \\
\hline Sum & & & $\sim 61^{*} 10^{6}$ & $\sim 28^{*} 10^{5}$ & $\sim 56.6^{*} 10^{5}$ \\
\hline CDs & SOC $\mathrm{kg} \mathrm{kg}^{-1}$ sediment & SOM kg kg-1 Sediment & Trapped sediment (kg) & Total SOC Trapped (kg) & Total OM Trapped (kg) \\
\hline Rim/Debre Yakob & 0.02 & 0.035 & $14.82 * 10^{5}$ & $29.64 * 10^{3}$ & $51.87^{*} 10^{3}$ \\
\hline Minizr/Adibera & 0.24 & 0.411 & $11.27^{*} 10^{5}$ & $270.48^{*} 10^{3}$ & $459.82^{*} 10^{3}$ \\
\hline Gosheye & 0.19 & 0.323 & $10.33^{*} 10^{5}$ & $196.33^{*} 10^{3}$ & $333.76^{*} 10^{3}$ \\
\hline Debre Mewi & 0.28 & 0.476 & $15.89 * 10^{5}$ & $445 * 10^{3}$ & $756.51^{*} 10^{3}$ \\
\hline Debre Tabor & 0.27 & 0.531 & $11.84^{*} 10^{5}$ & $319.68 * 10^{3}$ & $628.7^{*} 10^{3}$ \\
\hline Bure & 0.29 & 0.490 & $14.02 * 10^{5}$ & $406.65^{*} 10^{3}$ & $691.3^{*} 10^{3}$ \\
\hline Sum & & & $\sim 78 * 10^{5}$ & $16.68 * 10^{5}$ & $\sim 29.2 * 10^{5}$ \\
\hline
\end{tabular}




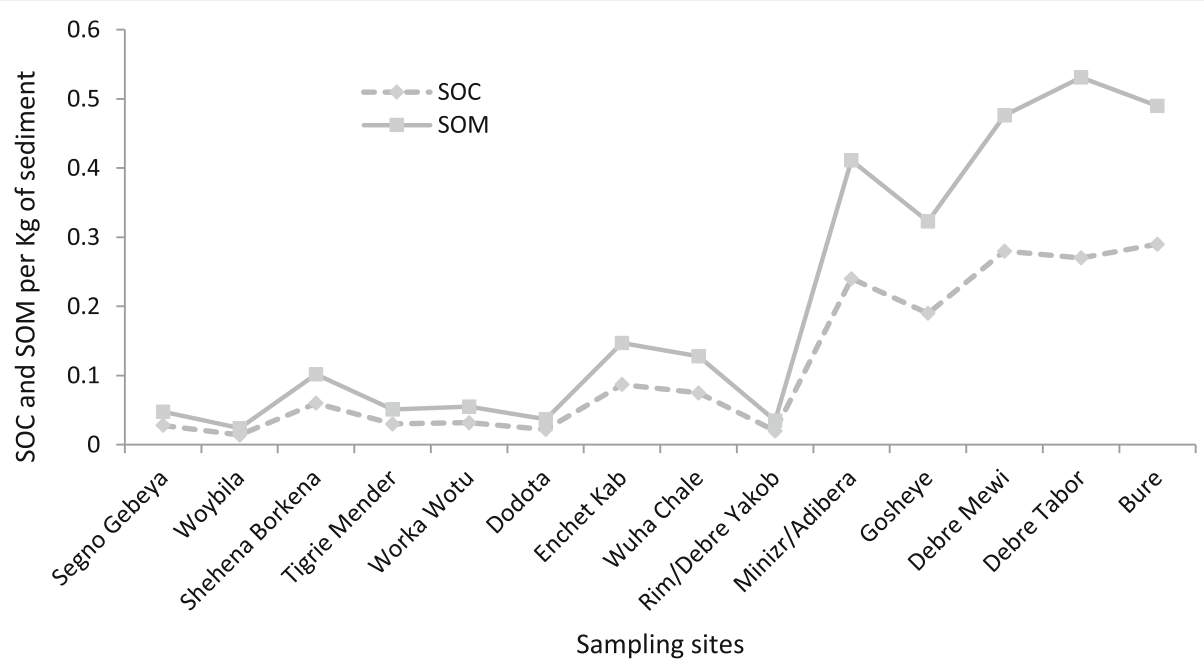

Fig. 3 Amount of SOC and SOM contained in a kilogram of sediment collected from fourteen locations

sediment. Dams are important practices in reducing downstream sedimentation problem. In addition to reducing downstream reservoirs sedimentation, SSDs contributed in conserving soil within the larger catchment and re-filling and stabilizing gullies. An SSD constructed at Woybila catchment within a gully, which is serving as a temporary drainage channel during the rainy seasons, trapped $\sim 22^{*} 10^{3} \mathrm{t}$ of sediment and refilled a $8 \mathrm{~m}$ deep and $20 \mathrm{~m}$ wide gully in 5 years reducing slope gradient by $12 \%$ on average, which can slow down the speed of runoff and give time for infiltration and sediment deposition. The sediment trapping role of dams of different sizes were evaluated by previous studies and proved their contribution. For example, Vorosmarty et al. (2003) noted that the world's registered 45,000 large dams can trap 4-5 billion $\mathrm{t} \mathrm{yr}^{-1}$ of sediment. In China more than
100,000 smaller check dams trapped 21 billion $\mathrm{m}^{3}$ of sediment (Wang et al., 2011). Sougnez et al. (2011) estimated the sediment volume trapped by 20 check dams in southern Spain as ranging from 4 to $920 \mathrm{~m}^{3}$. Sediment trapping dams not only help to trap sediment but also can be used to estimate sediment yield of the sediment contributing catchments above the dams, to refill gullies with sediment and reduce gully channel gradient.

\section{Sediment a sink for organic carbon}

Sediments trapped by sediment trapping dams or structures can potentially serve as carbon sinks (Poch et al. 2006; Harden et al. 2008; Van Oost et al. 2008; Cao et al. 2009, 2010; Zougmoré and Mando, 2010). Globally sedimentation resulting from soil erosion can sequester $\sim 1$ Pg C yr. ${ }^{-1}$ (Stallard 1998; Smith et al. 2001). Bao (2008),

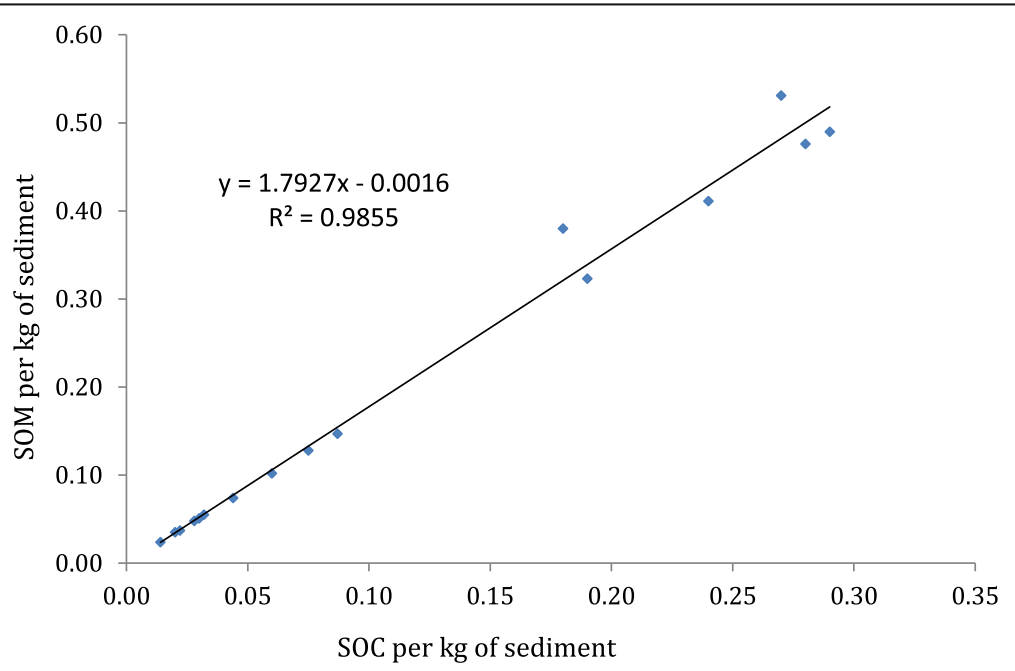

Fig. 4 the correlation between SOC and SOM contained in a kilogram of sediment collected from fourteen locations 
Wang et al. (2011) and Li et al., (2007) evaluated the SOC sequestration role of CDs and the result showed that CDs trapped over $21 * 10^{9} \mathrm{~m}^{3}$ with an average SOC content of $\sim 3.31 \mathrm{~g} \mathrm{~kg}^{-1}$ (Bao, 2008) and $0.952 \mathrm{Gt}$ with an average SOC content of $3.4 \mathrm{~g} \mathrm{~kg}^{-1}$ (Wang et al. 2011) and from 2 to $43 \mathrm{~g} \mathrm{~kg}^{-1}$ of sediment (Li et al., 2007). In this study, SSDs and CDs showed a great role in sequestering carbon in the form of SOC. SSDs trapped $60.97^{*} 10^{3} \mathrm{t}$ of sediment with the SOC content ranged from 14 to $87 \mathrm{~g} \mathrm{~kg}^{-1}$ and CDs trapped $7.8^{*} 10^{3} \mathrm{t}$ of sediment with the SOC ranged from 20 to $290 \mathrm{~g} \mathrm{~kg}^{-1}$. The SOC contents obtained within the trapped sediments are higher compared with other study findings mentioned above. The potential reason will be that the mass of SOC will vary spatially since the sources of carbon differ spatially. The possible sources of such SOC is decomposed crop stubbles, plant leaves and fertilizers applied in fields by farmers in addition to the nutrient content of the soil in the area. Moreover, the SOC content of sediments will increase when soil erosion is intensified and will decrease when soil erosion reduced. This means the quantity of SOC storage by sediments is controlled by the amount and type of organic residues that enter the soil (i.e. the input of organic $\mathrm{C}$ to the soil system) (FAO and ITPS, 2015).

SSDS and CDs also played an important role in trapping SOM. The SOM contents sediments trapped by SSDs and CDS ranged from 24 to $147 \mathrm{~g} \mathrm{~kg}^{-1}$ and $35-531 \mathrm{~g} \mathrm{~kg}^{-1}$ of sediment, respectively. The SOM content of sediments was higher than its SOC content. A kilogram of sediment contains $47-59 \%$ more SOM compared with SOC, which agreed well with the findings of FAO and ITPS, (2015) that is SOM contains roughly $55-60 \% \mathrm{C}$ by mass. The mass SOC and SOM contained in a kilogram of sediment also showed direct correlation with $\mathrm{R}^{2}=0.99$. The evaluated eight SSDs trapped $\sim 56.6^{*} 10^{5} \mathrm{SOM}$ together with $61^{*} 10^{6}$ $\mathrm{kg}$ sediment and six CDs trapped $29.2^{*} 10^{5}$ SOM together with $78^{*} 10^{5} \mathrm{~kg}$ sediment. This shows that SSDs and CDs are also important $C$ sinks. In general, the studied SSDs and CDs totally sequestered $85.8^{*} 10^{5} \mathrm{~kg}$ SOM together with $\sim 68.8^{*} 10^{6} \mathrm{~kg}$ of sediment, which is a great contribution in reducing the GHGs concentration in the atmosphere. It also helps to have a good knowledge of the current SOC and SOM sinks, its spatial distribution and its sinking mechanisms to inform various stakeholders (e.g. farmers, policy makers, land users) to provide the best opportunities to mitigate climate change. After carbon enters the soil in the form of organic material from soil fauna and flora, it can persist in the soil for decades, centuries or even millennia. When the soil carbon is released into the atmosphere it becomes an important source GHGs. Soils are major carbon reservoirs/sinks containing more carbon than the atmosphere and terrestrial vegetation (Lal, 2003; FAO and ITPS, 2015; FAO, 2017).

\section{Conclusion}

Sediment storage dams (SSDs) and check dams (CDs) were found to be important structural sediment trapping measures trapping large amount of carbon at the outlets of small sized catchments and within gullies. The eight SSDs and six CDs investigated, trapped a total of $50.5^{*} 10^{3} \mathrm{~m}^{3}$ or $\sim 68.8^{*} 10^{3} \mathrm{t}$ of sediment. In addition to trapping the sediment and reducing soil erosion SSDs and $\mathrm{CDs}$ played a promising role in sequestering soil organic carbon (SOC) and soil organic matter (SOM). The result shows that SSDs and CDs trapped from 14 to 87 and 20-290 g of SOC within a kilogram of sediment, respectively. In general, the studied SSDs and CDs sequestered $\sim 44.68^{*} 10^{5} \mathrm{~kg}$ of SOC together with $\sim 68.8^{*} 10^{6} \mathrm{~kg}$ of sediment. This means sediments are important reservoirs of SOC and plays an important role in reducing the amount of organic carbon that could be released to the atmosphere as a GHG. In conclusion, SSDs and CDs have retained substantial amount of carbon that could otherwise release to the atmosphere and contribute to global warming and thus SSDs and CDs can be used as climate change mitigation measures in additions to trapping sediments as soil and water conservation practices.

\section{Abbreviations \\ CDs: check dams; $\mathrm{CH}_{4}$ : Methane; $\mathrm{CO}_{2}$ : Carbon dioxide; FAO: Food and Agricultural Organization; GHGs: Greenhouse gases; IPCC: Intergovernmental panel on climate change; SOC: soil organic carbon; SOM: soil organic matter; SSDs: sediment storage dams}

\section{Acknowledgements}

This study would never be completed without the contribution of many people to whom we would like to express our gratitude. The administrative kebele's development agents, district agricultural officials, local guiders, committee leaders and respondent households in each of the sampling kebeles were indispensable for the successful completion of the field work. We would like also to acknowledge people who contributed their knowledge and time in data collection and entry processes.

\section{Funding}

Self-funded.

\section{Availability of data and materials}

The dataset supporting the conclusions of this article is included within the article.

\section{Declaration}

I, Solomon Addisu, holder of ORCID hereby declare that this research article is written by the authors whose names have been appropriately indicated.

\section{Authors' contributions}

MM has made substantial contributions in conception design, acquisition of data, and interpretation of results and leading the overall activities of the research; FA has been involved in data collection, entry, coding, and analysis. SA contributed in writing, drafting the manuscript, revising it critically for important intellectual content. He has given also the final approval of the version to be published. All authors read and approved the final manuscript.

Ethics approval and consent to participate

The authors hereby declare that, this manuscript is not published or considered for publication elsewhere.

Consent for publication

All authors read the manuscript and agree to publication. 


\section{Competing interests}

The authors declare that they have no competing interests.

\section{Publisher's Note}

Springer Nature remains neutral with regard to jurisdictional claims in published maps and institutional affiliations.

\section{Author details}

${ }^{1}$ Bahir Dar University, College of Agriculture and Environmental Sciences, P.o.box 5501 Bahir Dar, Ethiopia. ${ }^{2}$ Bahir Dar University, College of Agriculture and Environmental Sciences, P.o.box 1188 Bahir Dar, Ethiopia.

Received: 11 October 2018 Accepted: 16 April 2019

Published online: 10 May 2019

\section{References}

Baldocchi, D., Y. Ryu, and T. Keenan. 2016. Terrestrial carbon cycle variability, version 1. Issue 5

Bao, Y.X. 2008. The characteristics and evolution of soil nitrogen in Damland and terrace in loess hilly region. Xi'an, China: Northwest agriculture Forestry University press.

Cao, S.X. 2008. Impact of spatial and temporal scales on afforestation effects: Response to comment on "why large-scale afforestation efforts in China have failed to solve the desertification problem". Environmental Science and Technology 42: 7724-7725.

Cao, S.X., L. Chen, and X.X. Yu. 2009. Impact of China's grain for Green project on the landscape of vulnerable arid and semi-arid agricultural regions: A case study in northern Shaanxi Province. Journal of Applied Ecology 46: 536-543.

Cao, S.X., G.S. Wang, and L. Chen. 2010. Assessing effects of afforestation projects in China. Nature 466: 315-315.

Dean, W.E., and E. Gorham. 1998. Magnitude and significance of carbon burial in lakes, reservoirs, and peatlands. Geology 26: 535-538.

DeLaune, R.D., and J.R. White. 2012. Will coastal wetlands continue to sequester carbon in response to an increase in global sea level? A case study of the rapidly subsiding Mississippi river deltaic plain. Climate Change 110: 297-314.

FAO. 2017. Soil organic carbon: The hidden potential. Italy: Food and Agriculture Organization of the United Nations Rome.

FAO and ITPS. 2015. Status of the World's soil resources. Rome: Italy.

Harden, J.W., A.A. Berhe, M. Torn, J. Harte, S. Liu, and R.F. Stallard. 2008. Soil erosion: Data say C sink. Science 320: 178-179.

IPCC (2013) Summary for policymakers. In: Climate change 2013: The physical science basis. Contribution of working group I to the fifth assessment report of the intergovernmental panel on climate change [stocker, T.F., D. Qin, G. K. Plattner, M. Tignor, S.K. Allen, J. Boschung, A. Nauels, Y. Xia, V. Bex and P.M. Midgley (eds.)]. Cambridge University press, Cambridge, United Kingdom and New York, NY, USA.

IPCC. 2014. Climate change 2014: Synthesis, report contribution of working groups I, II and III to the fifth assessment report of the intergovernmental panel on climate change. Geneva: IPCC.

Jacinthe, P.A., R. Lal, L.B. Owens, and D.L. Hothem. 2004. Transport of labile carbon in runoff as affected by land use and rainfall characteristics. Soil and Tillage Research 77: 111-123.

Kayranli, B., M. Scholz, A. Mustafa, and A. Hedmark. 2010. Carbon storage and fluxes within freshwater wetlands: A critical review. Wetlands 30: 111-124.

Lal, R. 2003. Soil erosion and the global carbon budget. Environment International 29: 437-450.

Li, G.X., Z.B. Li, and X. Wei. 2007. Two key physical characteristics indexes of farmland sediment for check dams in loess plateau. Research of Soil and Water Conservation 14: 218-221.

McKenzie, N., K.J. Coughlan, and H. Cresswell. 2002. Soil physical measurement and interpretation for land evaluation. Collingwood, Victoria: CSIRO Publishing.

Mekonnen, M., S.D. Keesstra, J.E.M. Baartman, C.J. Ritsema, and A.M. Melesse. 2015 Evaluating sediment storage dams: Structural off-site sediment trapping measures in Northwest Ethiopia. CIG 41: 7-22.

Mekonnen, M., S.D. Keesstra, L. Stroosnijder, J.E.M. Baartman, and J. Maroulis. 2014. Soil conservation through sediment trapping: A review. Land Degradation \&d Development 26: 544-556.

MERET. 2008. MERET NEWS: A quarterly newsletter published by the Ministry of Agriculture and Rural Development, MERET, project coordination office, Bahir Dar, Ethiopia. Report No 5: 9-10.
Nelson DW, Sommers LE (1982) Total carbon, organic carbon and organic matter Methods of soil analysis. Part 2: Chemical and microbiological properties. Madison, Wisconsin.

Poch, R.M., J.W. Hopmans, J.W. Six, D.E. Rolston, and J.L. McIntyre. 2006 Considerations of a field-scale soil carbon budget for furrow irrigation. Agriculture, Ecosystems \& Environment 113: 391-398.

Smith, S.V., W.H. Renwick, R.W. Buddemeier, and C.J. Crossland. 2001. Methane oxidation in a peatland core. Global Biogeochemical Cycles 15: 697-707.

Sougnez, N., B. van Wesemael, and V. Vanacker. 2011. Low erosion rates measured for steep, sparsely vegetated catchments in Southeast Spain. Catena 84: 1-11.

Stallard, R.F. 1998. Terrestrial sedimentation and the carbon cycling: Coupling weathering and erosion to carbon burial. Global Biogeochemical Cycles 12: 231-257.

Van Oost, K., J. Six, G. Govers, T.A. Quine, and S. Gryze. 2008. Response to "soil erosion: A carbon sink or source?". Science 319: 1042.

Vorosmarty, C.J., M. Meybeck, B. Fekete, K. Sharma, P. Green, and J.P.M. Syvitski. 2003. Anthropogenic sediment retention: Major global impact from registered river impoundments. Global and Planetary Change 39: 169-190.

Wang, Y., B. Fu, L. Chen, Y. Lü, and Y. Gao. 2011. Check dam in the loess plateau of China: Engineering for environmental services and food security. Environmental Science and Technology 45: 10298-10299.

Zougmoré, R., and A. Mando. 2010. Benefits of integrated soil fertility and water management in semi-arid West Africa: An example study in Burkina Faso. Nutrient Cycling in Agroecosystems 88: 17-27.

\section{Submit your manuscript to a SpringerOpen ${ }^{\odot}$ journal and benefit from:}

- Convenient online submission

Rigorous peer review

- Open access: articles freely available online

- High visibility within the field

- Retaining the copyright to your article

Submit your next manuscript at $\boldsymbol{\nabla}$ springeropen.com 